\title{
Adoptive transfer of diabetes to and from old normoglycaemic BB rats
}

\author{
P. MacKay \\ Diabetes Immunology Department, Novo Nordisk, Bagsvaerd, Denmark
}

\begin{abstract}
Summary Approximately $4 \%$ of diabetes-prone BB/ Mol rats escape overt diabetes which occurs in other rats between 56 and 130 days of age. The ability of preactivated spleen cells from older non-diabetic and from acutely diabetic rats to adoptively transfer diabetes into young diabetes-prone rats was compared, and it was found that they transferred disease with similar incidence and with overlapping onset times in the recipients. Old non-diabetic rats were themselves susceptible to diabetes adoptively transferred from acutely diabetic or from old nondiabetic donors. Lymphocytic insulitis and pancreatic insulin content in unmanipulated old non-diabetic rats were both intermediate between those seen in acutely diabetic and in diabetes-resistant rats. In vivo treatment with polyinosinic-polycytidylic acid induced diabetes with faster onset in old non-diabetic rats than in young diabetes-prone rats. Adoptive
\end{abstract}

transfer of fresh, whole spleen cells from old nondiabetic rats did not protect young $\mathrm{BB}$ rats against spontaneous diabetes, while cells from diabetes-resistant rats did. Spleens from old non-diabetic rats contained significantly lower percentages of $\mathrm{T}$ cells than spleens from acutely diabetic rats but not lower than spleens from age-matched diabetic rats, suggesting that this reduction was age-related. Finally, spleens from both old non-diabetic and from acutely diabetic rats were negative for the regulatory $\mathrm{RT}^{+}{ }^{+} \mathrm{T}$-cell subset. It is concluded that quiescent beta-cell autoimmunity seen in a fraction of $\mathrm{BB} /$ Mol rats can be reactivated upon non-antigen-specific immune stimulation. [Diabetologia (1995) 38: 145-152]

Key words $\mathrm{BB}$ rats, autoimmunity, adoptive transfer, T lymphocytes, poly I:C.
The spontaneously diabetic Bio-Breeding (BB) rat is a model of human insulin-dependent diabetes mellitus (IDDM) in which $60-95 \%$ of both sexes become diabetic between the ages of 56-130 days (reviewed in reference [1]). The disease incidence and mean age of onset in a particular colony each depend on the family line from which it is derived [2] and both can be affected by environmental pathogens, diet

Received: 22 March 1994 and in revised form: 15 August 1994

Corresponding author: Dr. P. MacKay, Diabetes Immunology Department, Novo Nordisk, Novo Alle, DK-2880 Bagsvaerd, Denmark

Abbreviations: DP, Diabetes-prone; DR, diabetes-resistant; $O N D$, old non-diabetic; $A D$, acutely diabetic; $O D$, old diabetic; AT, adoptive transfer; NK, natural killer. and stress [3-5]. Diabetes-prone (DP) BB rats are lymphopenic, with reduced levels of T-helper cells [6] and low or undetectable numbers of $\mathrm{CD}^{+} /$ CD ${ }^{+}$cytotoxic $\mathrm{T}$ cells [7], and they lack the RT6 ${ }^{+}$ T-cell subset that prevents diabetes in the diabetesresistant (DR) strain [8,9]. The disease is T-cell dependent, as demonstrated by studies where diabetes was prevented by neonatal thymectomy [10] or by in vivo administration of anti-CD5 monoclonal antibody [11], and diabetes can be induced in young DP recipients by adoptive transfer of in vitro activated, purified $\mathrm{CD}^{+}{ }^{+} \mathrm{T}$ cells isolated from acutely diabetic (AD) donor rats [12]. Disease transfer is more efficient if $\mathrm{CD}^{+}$cells are co-purified with $\mathrm{CD} 4^{+} \mathrm{T}$ helper cells from the donor spleens [13], and recent studies have indicated that the necessary effector cells are $\mathrm{CD}^{+} \mathrm{T}$ cells $[14,15]$ and not $\mathrm{CD}^{+}$natur- 
al killer (NK) cells, which earlier studies had suggested $[11,16]$.

Although housed under identical conditions as future diabetics, some members of DP BB rat litters progress to adulthood with no clinical signs of disease and it is unclear why these inbred animals are not $100 \%$ concordant for diabetes. Previous studies have shown evidence of autoaggression to beta cells in old non-diabetic (OND) $\mathrm{BB}$ rats $[17,18]$, but it has also been suggested that long-term normoglycaemic BB rats have a suppressive lymphocyte population which, in the absence of in vitro preactivation, prevents the occurrence of spontaneous diabetes when inoculated into DP recipients [19]. In order to further elucidate these observations, I investigated (i) the ability of OND BB/Mol rats to serve as donors and as recipients in adoptive transfer (AT) experiments using preactivated spleen cells, (ii) the ability of non-activated OND spleen cells to transfer protection against disease, and (iii) the effect of immune activation in vivo by administration of polyinosinicpolycytidylic acid. The combined data provide new insight into the autoimmune status of these animals.

\section{Materials and methods}

Animals. DP and MHC-identical (RT1 $1^{\mathrm{w} u}$ ) DR BB rats were purchased from Møllegaard Animal Breeding Centre, Ll. Skensved, Denmark. At the time of study, DP rats had been inbred for more than 40 generations. The rats were housed at the Novo Nordisk animal facility on a 12-h light:dark cycle and fed ad libitum with standard rat chow and tap water. DP rats were monitored for weight loss three times a week and diabetes was diagnosed when blood glucose exceeded $11 \mathrm{mmol} / \mathrm{l}$ (Haemo-Glucotest sticks/Reflolux IIM, Boehringer Mannheim, Mannheim, Germany). Diabetic donor rats were treated with one daily injection of 15 IU heat-treated bovine UltraLente insulin (Novo Nordisk, Bagsvaerd, Denmark)/kg and killed by decapitation within 4 days of diagnosis. The spontaneous diabetes incidence in DP rats was $95.6 \%$ (1456 of 1523) and diabetes has never been observed in the DR substrain at Novo Nordisk. OND rats were confirmed as normoglycaemic (blood glucose $\leq 6.5 \mathrm{mmol} / \mathrm{l}$ ) immediately before entering experiments, the oldest one being 501 days of age. Twenty-one OND rats were observed until a mean age of $355 \pm 17$ days with no signs of diabetes.

Splenic lymphocyte preparation. Spleens were disrupted into single cells by rasping on stainless steel mesh and the mononuclear cells isolated by density gradient centrifugation on Lymphopaque $2 \%$ weight/volume Metrizamide (Nyegaard, Oslo, Norway). The cells were resuspended in basal medium consisting of RPMI 1640 supplemented with $2 \mathrm{mmol} / \mathrm{l}$ glutamine, $100 \mathrm{U} / \mathrm{ml}$ penicillin, $100 \mu \mathrm{g} / \mathrm{ml}$ streptomycin and $10 \%$ heat-inactivated fetal calf serum (Biological Industries, Kibbutz Beth Haemek, Israel). The phenotypic distribution of whole spleen mononuclear cells in AD and OND BB rats was analysed by fluorescence activated cell sorting (FACS) as described below.

For the preparation of donor cells for adoptive transfer, splenocytes were pooled from 3-6 rats and plastic adherent monocytes and B-lymphocytes were removed by panning twice for $30 \mathrm{~min}$ at $37^{\circ} \mathrm{C}$ on tissue culture dishes coated with rabbit anti-rat Ig (DAKO, Copenhagen, Denmark). The nonadherent fraction was incubated for $65 \mathrm{~h}$ at $37^{\circ} \mathrm{C}$ in $5 \% \mathrm{CO}_{2}$ in basal medium supplemented with $50 \mu \mathrm{mol} / \mathrm{l} 2$ 2-mercaptoethanol, $60 \mathrm{ng} / \mathrm{ml}$ phorbol myristate acetate (Sigma, St. Louis, Mo., USA), $0.6 \mu \mathrm{mol} / 1$ ionomycin (Serva, Heidelberg, Germany) and $10 \mathrm{U} / \mathrm{ml}$ recombinant human interleukin-2 (IL-2) (Boehringer Mannheim) (PII medium).

Flow cytometry. PII-activated non-adherent spleen cells were phenotyped immediately before adoptive transfer by incubating aliquots of $10^{5}$ cells at $4^{\circ} \mathrm{C}$ with fluorescein-isothiocyanate (FITC) conjugated OX19 anti-rat CD5 (pan T lymphocytes), phycoerythrin (PE) conjugated W3/25 anti-rat CD4 (T-helper cells and monocytes/macrophages), FITC-conjugated OX8 anti-rat CD8 (T-cytotoxic/suppressor and NK cells), PE-conjugated OX12 (anti rat $x$-chain) or PE-conjugated OX39 (IL-2 receptor) monoclonal antibodies (all from Serotec, Kidlington, UK).

For the analysis of mononuclear-cell subset distributions in whole spleen, aliquots were labelled with W3/25-PE, OX12PE, R73 (anti-rat T-cell receptor) ascites (Serotec) or OX8 hybridoma supernatant (Seralab, Crawley Down, Sussex, UK). These four products were free of non-specific binding to whole BB rat spleen. R73 and OX8-labelled cells were developed for FACS analysis by incubation with rat-adsorbed, biotinylated horse anti-mouse Ig (Vector Laboratories, Burlingame, Calif., USA), followed by FITC-conjugated streptavidin (DAKO).

T-cell expression of the RT6.1 and RT6.2 alloantigens was investigated by labelling spleen cells, depleted of $B$ cells and macrophages as explained above, with rat anti-RT6.1 and anti-RT6.2 monoclonal antibodies (kindly supplied by Dr. J. Mordes, Worcester, Mass., USA), followed by FTTC-conjugated rabbit anti-rat Ig (DAKO).

All incubations were carried out in phosphate buffered saline (PBS) with $1 \%$ bovine serum albumin and $0.1 \% \mathrm{NaN}_{3}$ using saturating concentrations of antibodies. After Labelling the cells were washed once in assay buffer, once in PBS alone and then fixed in $1 \%$ formaldehyde. Ten thousand cells were analysed by FACScan (Becton Dickinson, San Jose, Calif., USA), dead cells and erythrocytes being excluded by electronic gating. The percentages of stained cells were computed by Lysis software.

Adoptive transfer of diabetes. PII-activated cells were washed, counted and analysed by FACS, after which aliquots containing a given number of $\mathrm{OX} 19^{+}$cells plus additional co-purified $\mathrm{OX} 8^{+}$cells were injected into the tail vein of recipient rats in $1 \mathrm{ml}$ of neat RPMI. Three types of adoptive transfer experiments were performed. In one set of experiments, PII-activated cells from AD (age 65-111 days) or from OND BB rats (age 122-179 days) were injected into 4-week-old DP rats, while sex-matched littermates received RPMI alone. In another set of experiments, activated cells prepared from $\mathrm{AD}$ donors were injected into OND rats (age 130-173 days), while age-matched OND controls (age 134-183 days) received RPMI alone. Blood glucose was monitored daily and when it exceeded $11 \mathrm{mmol} / \mathrm{l}$ cell recipients were killed for evaluation of pancreas histology. Control rats were killed for histologic examination when the last cell recipient in a given experiment became diabetic or, in the case of one experiment, at age 60 days.

Induction of diabetes with poly I:C. Every second day, four OND rats (age $164 \pm 12$ days), four young DP (39 \pm 1 days) and four adult DR rats (124 \pm 0 days) were treated i.p. with 


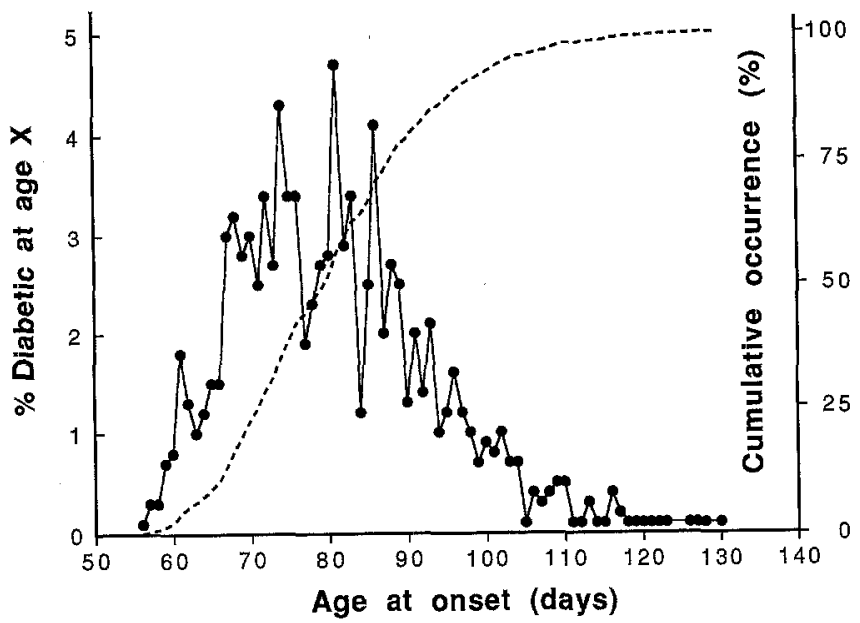

Fig. 1. Frequency distribution of onset age $(\rightarrow-)$ and cumulative occurrence of spontaneous diabetes (-..) in $\mathrm{BB} / \mathrm{Mol}$ rats $(n=1456)$

Table 1. Adoptive transfer of diabetes from old non-diabetic (OND) and from acutely diabetic (AD) BB rats into young diabetes-prone recipients

\begin{tabular}{|c|c|c|c|c|}
\hline \multirow[t]{2}{*}{ Inoculum } & \multicolumn{2}{|c|}{ Cells transferred $\times 10^{6}$} & \multirow{2}{*}{$\begin{array}{l}\text { Incidence } \\
(n)\end{array}$} & \multirow{2}{*}{$\begin{array}{l}\text { Insulitis } \\
\text { score }\end{array}$} \\
\hline & $\mathrm{OX} 19^{+}$ & $\mathrm{OX} 8^{+}$ & & \\
\hline OND cells ${ }^{\mathrm{a}}$ & $7.5 \pm 0.3$ & $1.0 \pm 0.2$ & $8 / 9$ & $3.79 \pm 0.10^{c}$ \\
\hline AD cells & $7.6 \pm 0.4$ & $1.6 \pm 0.4$ & $10 / 10^{\mathrm{b}}$ & $3.64 \pm 0.08^{c}$ \\
\hline Medium & NA & NA & $0 / 7$ & $0.37 \pm 0.20$ \\
\hline
\end{tabular}

Values are expressed as means \pm SEM for numbers of rats indicated ( $n=5$ experiments).

${ }^{a}$ No statistically significant differences between OND and AD cell recipients in any parameter listed; ${ }^{b} p<0.002$ vs mediuminjected controls; ${ }^{c} p<0.002$ vs medium-injected controls. NA, not applicable

polyinosinic-polycytidylic acid at a dose of $5 \mu \mathrm{g} / \mathrm{g}$ body weight (poly I:C, Pharmacia, Uppsala, Sweden). As controls, three OND (152 \pm 16 days) and four DP (39 \pm 1 days) rats were injected with a corresponding volume of vehicle $(154 \mathrm{mmol}$ $\mathrm{NaCl} / 1 \mathrm{H}_{2} \mathrm{O}$ ) and all animals were monitored daily for hyperglycaemia. For evaluation of pancreas histology, diabetic animals were killed at diagnosis, controls when the last poly I:Ctreated rat in a group became diabetic or, in the case of poly I:C-treated DR rats, 24 days after commencement.

Prevention of spontaneous diabetes by transfer of fresh spleen cells. In order to investigate the presence of diabetes-suppressive cells, whole spleen mononuclear cells were prepared from OND (age $193 \pm 9$ days, $n=7$ ) and from DR donor rats (age $157 \pm 9$ days, $n=6$ ). Thirty-one day female $D P$ rats from two litters were divided into matched groups and each rat injected i.v. with $152 \times 10^{6}$ pooled OND or DR cells. At diagnosis of diabetes, or in the case of non-diabetic rats at age 130 days, lymphocytes were prepared from individual spleens, enriched for $\mathrm{T}$ cells by negative panning as explained above, and then analysed by FACS for the presence of RT6 ${ }^{+}$cells. Pancreata were excised for histologic examination.

Pancreatic examinations. Pancreata were removed from nine unmanipulated OND (age $168 \pm 6$ days), from nine acutely diabetic (age $80 \pm 3$ days) and from four DR rats (age $93 \pm 0$ days) and cleaned of excess fat. A small section was snapfrozen for histologic examination while the remaining section was weighed and stored at $-80^{\circ} \mathrm{C}$ for subsequent determination of insulin content.

For quantitation of lymphocytic insulitis in these and in other rats studied, pancreas sections were stained with haematoxylin and eosin and scored as follows: $0=$ no mononuclear cell (MNC) infiltration, 1 = few MNC at vascular areas, intact islet structure, 2 = many $\mathrm{MNC}$ in and around islet, intact islet structure, 3 = highly infiltrated islet, only small areas of intact islet tissue, $4=$ islet beta cells totally destroyed. For each animal 10 to 20 islets were scored by light microscopy of coded slides.

For the determination of insulin content, stored sections were thawed and then homogenized and ultrasonicated in $75 \%$ ethanol, $1.5 \% 12 \mathrm{~mol} / 1 \mathrm{HCl}, 23.5 \% \mathrm{H}_{2} \mathrm{O}$. Insulin was extracted overnight at $4{ }^{\circ} \mathrm{C}$ in this buffer and the extracts neutralized with $1 \mathrm{~mol} / \mathrm{N} \mathrm{NaOH}$ after which immunoreactive rat insulin was determined by radioimmunoassay [20] and expressed as $\mathrm{ng}$ insulin/mg wet pancreas.

\section{Statistical analysis}

Results are expressed as means \pm SEM. Diabetes incidence in different experimental groups was compared by the Fisher exact test (two-tailed), while all other data were analysed by the Mann-Whitney U-test. Statistical significance was assumed at $p<0.05$.

\section{Results}

Diabetes frequency and onset age distribution. The historic incidence of spontaneous diabetes in $\mathrm{BB} /$ $\mathrm{Mol}$ rats was $95.6 \%$ (1456 of 1523). The youngest diabetic rat was 56 days old while the oldest was diagnosed at 130 days and the mean age of onset was 79.5 days. The onset age distribution and the cumulative occurrence of diabetes are shown in Figure 1. The age of onset is skewed to the left and tapers off as the rats grow older than 100 days. Thus, in the first 20 days (56-75 days) of diabetes occurrence, $38.9 \%$ of all eventual diabetics were diagnosed, while only $2.2 \%$ were diagnosed in the last 20 days $(111-130$ days).

Adoptive transfer using $O N D$ donor rats. FACS analysis of negatively panned, PII-activated spleen cells from both OND and from AD rats ( $n=5$ experiments) showed each donor cell type to be nearly equally positive for OX19 (pan T cells) and W3/25 (T-helper cells). OND cells were $85.9 \pm 2.8 \mathrm{OX}^{\circ} 9^{+}$, $84.6 \pm 3.0 \% \quad \mathrm{~W} 3 / 25^{+} \quad(p=\mathrm{NS} \quad$ vs $\mathrm{OX} 19)$ and $12.3 \pm 2.5 \% \mathrm{OX}^{+}$. OX19 plus OX8 accounted for $98.2 \pm 0.85 \%$ of the total populations. PII-activated cells from AD donors were $78.7 \pm 4.1 \%$ OX19 ${ }^{+}$, $79.3 \pm 4.3 \% \mathrm{~W} 3 / 25^{+}$and $16.6 \pm 3.3 \% \mathrm{OX}^{+}$. OX 19 plus OX8 accounted for $95.3 \pm 1.6 \%$ of the total AD populations, the remainder being contaminating $B$ cells. The transferred cells from each donor type 


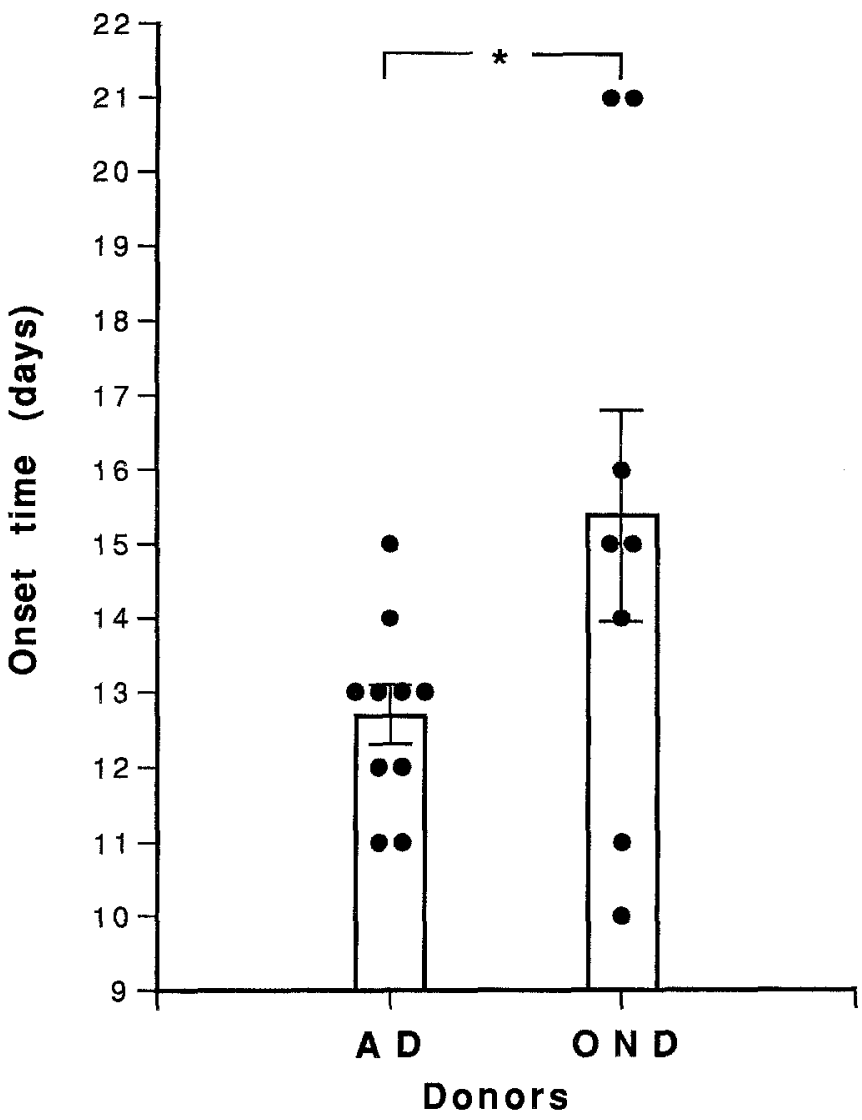

Fig. 2. Individual onset times in young diabetes-prone rats rendered diabetic by adoptive transfer of cells from acutely diabetic (AD) or old non-diabetic (OND) donors, as documented in Table 1. Columns represent means \pm SEM. ${ }^{*} p=\mathrm{NS}$

were thus composed essentially of T-helper and NK cells, but lacking the resolution afforded by double labelling they are referred to here as T + NK cells. They were over $90 \% \mathrm{OX} 39^{+}$(IL-2 receptor) in all cases.

As shown in Table 1, eight out of nine young DP recipients injected with activated $\mathrm{T}+\mathrm{NK}$ cells from OND donors became diabetic. The one non-diabetic recipient advanced to adulthood without ever becoming hyperglycaemic. All of the $10 \mathrm{DP}$ rats injected with a similar number of $\mathrm{T}+\mathrm{NK}$ cells from AD donors became diabetic ( $p=\mathrm{NS}$ vs OND), while all medium-injected rats remained normoglycaemic ( $p<0.002$ vs OND or AD cell recipients). The islets in recipients of either OND or of AD cells were totally destroyed, while infiltrating mononuclear cells were seen only in a few islets in the control group $(p<0.002)$.

The individual onset times of the diabetic rats are depicted in Figure 2, which shows that the onset times of $\mathrm{AD}$-cell recipients spanned a narrow range of 11-15 days (mean \pm SEM $12.7 \pm 0.4$ days), while the onset times of OND-cell recipients spanned a wider - but completely overlapping range of 10-21 days (mean $\pm \mathrm{SEM}=15.4 \pm 1.4$ days, $p=\mathrm{NS}$ ).

Adoptive transfer using $O N D$ recipient rats. In three experiments, five OND rats were injected with populations of preactivated $\mathrm{T}+\mathrm{NK}$ cells from acutely diabetic DP donors. All of them became diabetic within 8-11 days, while all age-matched controls remained normoglycaemic ( $p<0.01$, Table 2$)$. Lymphocytic infiltration and beta-cell destruction were significantly more pronounced in cell recipients than in controls $(p<0.01)$.

In order to exclude that diabetes transferred to or from OND rats was dependent on a contributing mononuclear cell population present only in $\mathrm{AD}$ donors or in young DP recipients, two OND rats (aged 324 and 501 days) were injected with activated OND $\mathrm{T}+\mathrm{NK}$ cells. One rat which received $3.0 \times 10^{6}$ $\mathrm{OX} 19^{+}$plus $1.8 \times 10^{6} \mathrm{OX}^{+}$cells became diabetic after 29 days, and the other, which received $3.8 \times 10^{6}$ OX $19^{+}$plus $2.1 \times 10^{6} \mathrm{OX}^{+}$cells, became diabetic after 25 days. The insulitis scores of the cell recipients were 3.60 and 4.00 , respectively, while the mean score of five OND controls (age 299-389 days) was $2.15 \pm 0.64$ (data not presented in Table form).

Induction of diabetes by poly I:C. As shown in Table 3 , all OND rats treated with poly I:C became diabetic, whereas no NaCl-treated OND controls did $(p=0.06)$. Likewise, all poly I:C-treated young DP rats became diabetic, while no $\mathrm{NaCl}$-treated DP controls became diabetic within the study period $(p<0.03)$. In contrast to poly I:C-treated OND and DR rats, all the poly $\mathrm{I}: C$-treated DR rats remained normoglycaemic until killed 24 days after commencement ( $p<0.03$ vs OND or DP rats). The mean onset time of poly I:C-treated OND rats was significantly shorter (range 2-8 days) than that of poly I:C-treated DP rats (range 11-24 days, $p<0.03$ ).

Histologic examination revealed lymphocytic infiltration and severe islet-cell destruction in the poly I:C-treated OND rats, while the NaCl-treated OND

Table 2. Adoptive transfer of diabetes from acutely diabetic (AD) into old non-diabetic BB rats

\begin{tabular}{|c|c|c|c|c|c|c|}
\hline \multirow[t]{2}{*}{ Inoculum } & \multirow{2}{*}{$\begin{array}{l}\text { Recipient age } \\
\text { at transfer (days) }\end{array}$} & \multicolumn{2}{|c|}{ Cells transferred $\times 10^{6}$} & \multirow{2}{*}{$\begin{array}{l}\text { Incidence } \\
(n)\end{array}$} & \multirow{2}{*}{$\begin{array}{l}\text { Onset time } \\
\text { (days) }\end{array}$} & \multirow[t]{2}{*}{ Insulitis score } \\
\hline & & $\overline{\mathrm{OX} 19^{+}}$ & $\mathrm{OX8}^{+}$ & & & \\
\hline AD cells & $153 \pm 8$ & $6.0 \pm 0.0$ & $2.4 \pm 0.2$ & $5 / 5^{\mathrm{a}}$ & $9.8 \pm 0.5$ & $3.93 \pm 0.06^{b}$ \\
\hline
\end{tabular}

Values are means \pm SEM for numbers of rats indicated ( $n=3$ experiments).

${ }^{\mathrm{a}} p<0.01$ vs controls; ${ }^{\mathrm{b}} p<0.01$ vs controls 
Table 3. Induction of diabetes in old non-diabetic (OND) and in young diabetes-prone (DP) rats by polyinosinic-polycytidylic acid (poly I: C)

\begin{tabular}{llllll}
\hline Rats & Treatment & Age (days) & Incidence $(n)$ & Onset time (days) & Insulitis score \\
\hline OND & Poly I:C & $164 \pm 12$ & $4 / 4^{\mathrm{a}}$ & $5.5 \pm 1.3^{\mathrm{d}}$ & $3.74 \pm 0.25^{\mathrm{e}}$ \\
OND & NaCl & $152 \pm 16$ & $0 / 3$ & NA & $1.92 \pm 0.41$ \\
Young DP & Poly I:C & $39 \pm 1$ & $4 / 4^{\mathrm{b}}$ & $16.0 \pm 3.0$ & $3.61 \pm 0.21^{\mathrm{e}}$ \\
Young DP & NaCl & $39 \pm 1$ & $0 / 4$ & NA & $1.32 \pm 0.70$ \\
DR & Poly I:C & $124 \pm 0$ & $0 / 4^{\mathrm{c}}$ & NA & $0.83 \pm 0.25$ \\
\hline
\end{tabular}

Values are means \pm SEM for numbers of rats indicated $(n=1$ experiment). DR, diabetes-resistant rats; NA, not applicable.

${ }^{\mathrm{a}} p=0.06$ vs $\mathrm{NaCl}$-treated $\mathrm{OND} ;{ }^{\mathrm{b}} p<0.03$ vs $\mathrm{NaCl}$-treated
DP; ${ }^{c} p<0.03$ vs poly I: C-treated OND or DP rats; ${ }^{\mathrm{d}} p<0.03$

vs poly I: C-treated DP; ${ }^{\mathrm{e}} p<0.04$ vs $\mathrm{NaCl}$-treated controls

Table 4. Inability of fresh OND spleen cells to transfer protection against spontaneous diabetes

\begin{tabular}{llllcc}
\hline Inoculum & Cells transferred $\times 10^{6}$ & Incidence & $\begin{array}{l}\text { Age at onset } \\
\text { (days) }\end{array}$ & $\begin{array}{l}\text { RT6.1 expression on } \\
\text { recipient spleen cells }\end{array}$ \\
\hline OND cells & 152 & $4 / 4$ & $61.3 \pm 3.5$ & $1.4 \pm 0.3 \%$ & \multicolumn{1}{c}{$\begin{array}{l}\text { Insulitis score } \\
\text { DR cells }\end{array}$} \\
\hline
\end{tabular}

Values are means \pm SEM for number of rats indicated ( $n=1$ experiment). DR, Diabetes-resistant.

${ }^{\mathrm{a}} p<0.02 ;{ }^{\mathrm{b}} p<0.015 ;{ }^{\mathrm{c}} p<0.015$ vs $\mathrm{OND}$ cell recipients. NA, not applicable

Table 5. Subset distributions and recoveries of spleen cells from BB rats

\begin{tabular}{lccc}
\hline & AD $(n=11)$ & OND $(n=10)$ & OD $(n=7)$ \\
\hline Subset & & & $14.30 \pm 0.79$ \\
R73 & $16.03 \pm 0.65^{\mathrm{a}}$ & $13.54 \pm 0.56$ & $11.88 \pm 1.33^{\mathrm{b}}$ \\
W3/25-R73 & $16.83 \pm 1.53$ & $17.57 \pm 1.04$ & $45.28 \pm 3.36$ \\
OX12 & $49.25 \pm 1.51$ & $49.29 \pm 2.50$ & $26.81 \pm 2.27^{\mathrm{c}}$ \\
OX8 & $15.47 \pm 1.23$ & $18.22 \pm 1.97$ & $98.3 \pm 1.0$ \\
Total spleen subsets & $97.6 \pm 2.0$ & $98.6 \pm 1.4$ & $66 \pm 9$ \\
Recovery $\times 10^{6}$ & $77 \pm 5$ & $164 \pm 3$ & $163 \pm 9$ \\
Age (days) & $78 \pm 3$ & $167 \pm 6$ & \\
\hline
\end{tabular}

FACS analysis of spleen cell subsets from acutely diabetic (AD), from old non-diabetic (OND) and from old diabetic (OD) rats, defined by monoclonal antibodies R73 (T cells), R73 minus W3/25 (macrophages), OX12 (B cells)

controls had significantly lighter infiltrates and larger islets $(p<0.04$, Table 3$)$. Pancreata from poly I:Ctreated young DP rats all showed end-stage islets, whereas NaCl-treated DP controls had significantly lighter MNC infiltrations $(p<0.04)$. The islets of poly I:C-treated DR rats had few infiltrating cells and appeared intact. Pancreata from the poly I:Ctreated rats were smaller than those of control rats and in some cases revealed mild exocrine pancreatitis.

Inability of fresh OND spleen cells to prevent spontaneous diabetes. All of the young DP rats transfused with fresh OND spleen cells had become diabetic by 52-69 days of age, while no DP rats injected with the same number of fresh DR cells were hyperglycaemic by age 130 days $(p<0.02$, Table 4$)$. FACS analysis of individual spleens after enrichment for $\mathrm{OX} 19^{+}$and $\mathrm{OX}^{+}$cells by negative panning showed DR-cell recipients to have engrafted RT6.1 ${ }^{+}$cells at age 130 and $\mathrm{OX} 8$ (NK cells). Values are means \pm SEM; $n=$ numbers of rats studied.

${ }^{\mathrm{a}} p<0.02$ vs OND and NS vs OD; ${ }^{\mathrm{b}} p<0.01$ vs $\mathrm{AD}$ and vs OND; ${ }^{c} p<0.02$ vs AD and vs OND

days, while the OND cell recipients had few, if any, such cells at diagnosis $(p<0.015)$. The percentage of $\mathrm{OX} 19^{+}$cells was twice as high in DR-cell recipients as in OND-cell recipients and this T-cell population consisted of both $\mathrm{CD}^{+}{ }^{+}$and of $\mathrm{CD} 8^{+} \mathrm{T}$ cells, the latter subset being undetectable in recipients of OND cells (data not shown).

Histologic examination revealed that the beta cells of OND-cell recipients were totally destroyed ( $\mathrm{Ta}-$ ble 4), the remaining islet cells staining positive for glucagon only (not shown). By contrast, the islets of DR-cell recipients were completely free of lymphocytic infiltration $(p<0.015)$.

Pancreatic examinations of $A D, O N D$ and $D R$ rats. Microscopic examination of pancreata from AD DP rats revealed uniformly heavy lymphocytic infiltration and beta-cell destruction (Fig. 3A), while those from OND rats spanned a wide range from mild to heavy infiltration, but with a significantly lower 

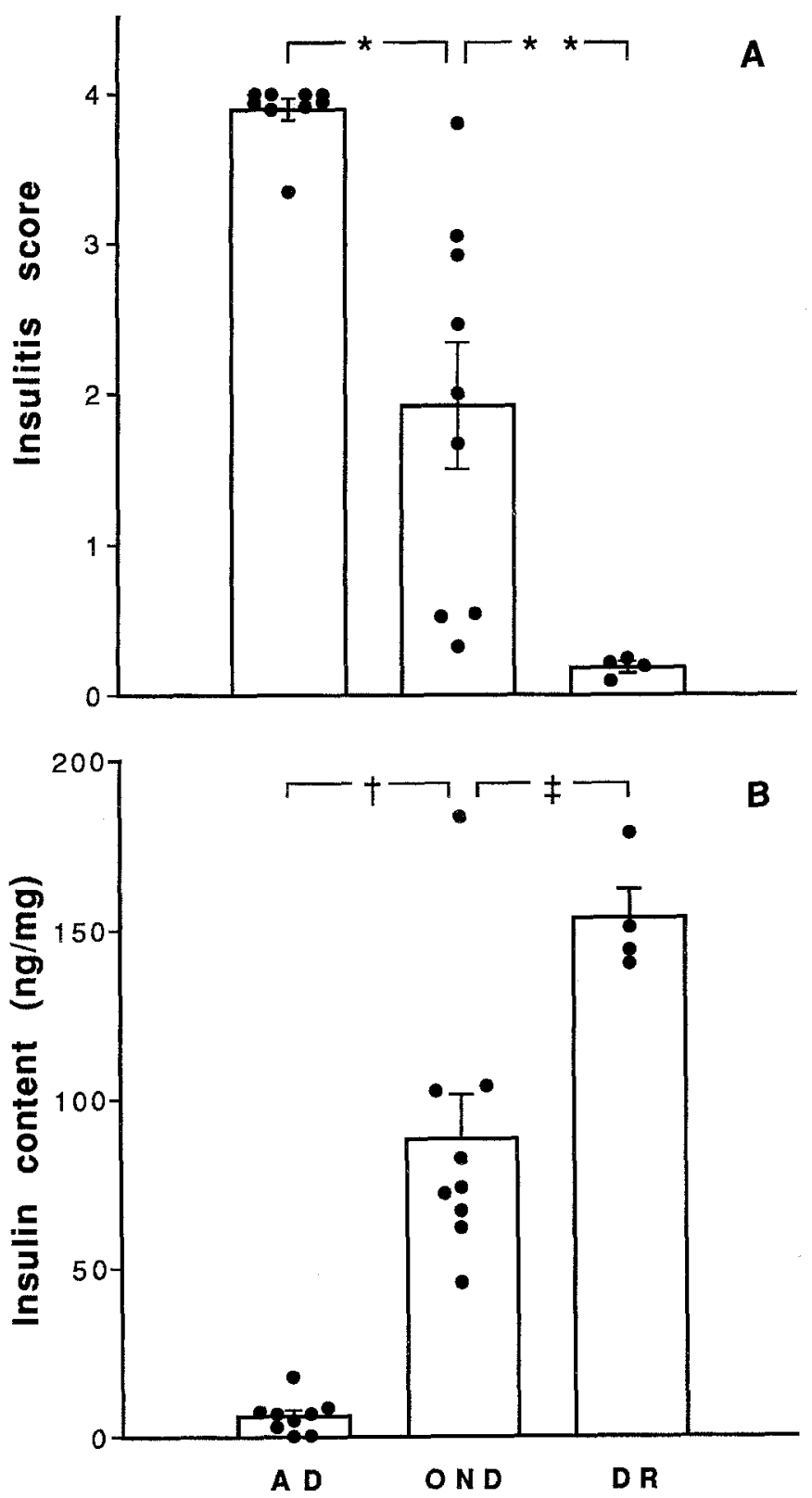

Fig. 3 (A, B) Individual insulitis scores (A) and insulin contents $(\mathbf{B})$ in pancreata from acutely diabetic (AD, $n=9)$, old non-diabetic (OND, $n=9)$ and diabetes-resistant (DR, $n=4)$ $\mathrm{BB}$ rats. Columns represent means $\pm \mathrm{SEM}$.

${ }^{*} p<0.0005 ;{ }^{* *} p<0.006 ; \dagger p<0.0005$ and $\$ p<0.05$

mean insulitis score than $\mathrm{AD}$ rats $(p<0.0005)$. Pancreata from control DR rats were free of insulitis $(p<0.006$ vs OND rats).

Measurements of insulin content in these same pancreata (Fig. 3B) showed AD rats to be nearly devoid of immunoreactive insulin. OND rats contained significantly more insulin per mg pancreas than $\mathrm{AD}$ rats $(p<0.0005)$, but significantly less than DR rats $(p<0.05)$. In the three groups together, insulitis was inversely correlated with insulin content $(p<0.001$ by regression analysis, not shown), but within the OND group itself the correlation did not reach statistical significance.
Spleen-cell subset determinations. Spleen mononuclear cells were isolated from individual $\mathrm{AD}$, from OND and from old diabetic (OD) rats that had been treated with insulin for a disease duration of $83 \pm 10$ days. Splenocyte yields from AD, OND and OD rats were not significantly different (Table 5). OND rat spleens had a significantly lower mean percentage of $\mathrm{R}^{+} 3^{+}$(T-cell receptor) cells than $\mathrm{AD}$ rats, but it was not significantly different from the mean percentage of $\mathrm{R} 73^{+}$cells found in age-matched OD rats. $\mathrm{R} 73$ always correlated with the $\mathrm{W} 3 / 25^{+} \mathrm{T}$ (helper) cell histogram peak clearly seen with the latter antibody (not shown). There were no differences between AD and OND rats in the percentages of $\mathrm{W} 3 / 25^{+}, \mathrm{R} 73^{-}$ cells (macrophages), $\mathrm{OX} 12^{+}$(B) cells or $\mathrm{OX}^{+}$ (NK) cells, but OD rats had significantly lower percentages of macrophages than OND and AD rats, and significantly higher percentages of $\mathrm{OX}^{+}$cells than $\mathrm{AD}$ and OND rats. In each group of rats analysed, the sum of subsets accounted for by R73, W3/ 25-R73, OX12 and OX8 was more than $97 \%$.

FACS analysis of RT6 alloantigen expression on fresh $\mathrm{T}+\mathrm{NK}$ populations showed that both $\mathrm{AD}$ and OND rats were negative for RT6.1 and RT6.2 (not shown).

Serologic status. Serum samples from AD and OND rats were analysed for antibodies to seven common rodent viruses and for antibodies to Mycoplasma pulmonis and Bacillus piliformis (Prof. V. Kraft, Central Institute for Animal Breeding, Hannover, Germany). Two out of $13 \mathrm{OND}$ and 3 out of $18 \mathrm{AD}$ rats were seropositive for Kilham's rat virus $(p=\mathrm{NS})$ and all rats were seronegative for other viruses assayed (SDAV, Reo3, TMEV, PVM and Sendai virus). Seven out of 13 OND and 10 out of $18 \mathrm{AD}$ rats were seropositive for Bacillus piliformis ( $p=\mathrm{NS}$ ) and all rats were seronegative for Mycoplasma pulmonis.

\section{Discussion}

The present study shows that DP BB rats which have escaped clinical diabetes nonetheless have the ability to adoptively transfer the disease to young DP rats with a similar frequency and mean onset time as when AD donors are used. Since the onset time of adoptively transferred diabetes in BB rats depends on the number of $\mathrm{CD}^{+}{ }^{+}$cells in the transferred population [21], and since total spleen $T$ cells numbers were not lower in OND than in AD rats (Table 5), it appears that non-progression to overt diabetes in OND rats is not related to significantly lower numbers of diabetogenic $\mathrm{T}$ cells, but more probably to their insufficient activation.

The reduced insulin content in OND pancreata suggest that some beta-cell damage has taken place and the lower insulitis scores seen in OND, com- 
pared to $\mathrm{AD}$ rats, show that immunocyte homing into the islets is less efficient in the former group, some of which were free of insulitis. Upon treatment with the interferon inducer poly $\mathrm{I}: \mathrm{C}$, which accelerates the age of onset in young DP rats [22], lymphocytic infiltration is resumed and the rats become diabetic, suggesting that OND rats are in a state of quiescent beta-cell autoimmunity. Interferon- $\gamma$ has been implicated in diabetes pathogenesis at several levels, such as lymphocyte homing [23], stimulation of MHC and adhesion molecule expression on beta cells [24] and, in synergy with other cytokines, as a beta-cell toxic agent [25]. Non-occurrence of diabetes in OND rats may thus be related to lower interferon production in these than in rats which do become diabetic.

The skewed shape of the onset age curve in diabetic rats (Fig. 1) may reflect immune reactivity to a delayed-expressed autoantigen to which DP rats are intolerant, such as the $38 \mathrm{kDa}$ islet-cell protein described by Ko et al. [26]. This autoantigen is expressed in the islets of neonatal DR rats, but only after 30 days of age in DP rat islets which then acquire immune target status. In future OND rats this autoantigen may be expressed at an earlier age than in future diabetic rats, thus leading to some degree of tolerance. Alternatively, inductive autoantigen(s) could be expressed only transiently or at continually low levels in OND rats, resulting in inadequate T-cell activation and incomplete subsequent beta-cell destruction.

Another possible cause of the skewed shape of the onset age curve could be the action of regulatory cells that dampen the disease frequency as the animals grow older, rescuing $4 \%$ of the population from diabetes. Evidence of suppressive cells was provided by Kuttler et al. [19] who found that spontaneous diabetes was prevented in $\mathrm{DP} \mathrm{BB} / \mathrm{OK}$ rats by transfusions of $25 \times 10^{6}$ fresh, whole mononuclear cells from OND donors. In the present study, all recipients of fresh OND spleen cells became diabetic, whether using the same (not shown) or a sixfold higher cell dose than Kuttler et al. [19] (Table 4), an observation that argues against a role for suppressive cells in OND BB/Mol rats. It is possible, however, that some $\mathrm{BB} / \mathrm{OK}$ rats have a higher ratio of suppressive:diabetogenic mononuclear cells than do $\mathrm{BB} / \mathrm{Mol}$ rats, a notion which could explain both the lower diabetes incidence and the higher mean age of onset characteristic of the $\mathrm{BB} / \mathrm{OK}$ subline [19], as well as the preventive effect of transfused OND donor cells.

Non-occurrence of diabetes in OND rats could theoretically be related to defective accessory cell function. In experiments reported elsewhere [27], no difference was detected in OND and AD spleen cell reactivity to concanavalin $A$, suggesting that presentation to $\mathrm{T}$ cells of at least this lectin was intact in OND rats. In vitro cytotoxicity of OND and AD spleen cells to rat insulinoma cells did not differ either [27], but in view of the postulated role of CD8 ${ }^{+}$
T cells in BB rat diabetes [14], cytotoxicity assays in the presence of NK cells (and using MHC incompatible target cells) may be futile.

In a previous study, virus seropositive DP rats had a reduced disease incidence and a later mean age of onset than seronegative rats [3]. In the animals analysed in the present study, no correlation was evident between serologic status and the occurrence of diabetes, but a role for micro-organisms in OND rats during a critical earlier period cannot be ruled out, since prospective serum samples were not collected.

Commensurate with the reduced insulin content demonstrated herein and by others [18] in the pancreata of OND rats, these animals have impaired beta-cell function [28]. In humans, impaired first phase insulin release is seen in first-degree relatives of individuals with IDDM [29] and in non-diabetic members of identical twin pairs where the index twin is diabetic [30]. The concordance rate of diabetes in monozygotic twins is reportedly only some $54 \%$ [31] and it has been speculated that this is the result of exposure to different environmental influences (reviewed in [32]). The observation that poly I:C induces diabetes in OND BB rats supports the notion that non-antigen specific exogenous factors which stimulate cytokine production can precipitate disease in diabetes-prone humans who may otherwise be in a quiescent state of autoimmunity. Elucidation of the mechanisms that limit the degree of betacell destruction in OND BB rats may help explain why a genetically diabetes-prone person not always progress from subclinical to overt IDDM.

Acknowledgements. I thank Ms. L. Studstrup for expert technical assistance, Mr. S. Kryger for preparing histology slides, Dr. A. Moody for performing insulin assays and Dr. J. Mordes for supplying anti-RT6 antibodies.

\section{References}

1. Parfrey NA, Prud'homme GJ, Colle E, Fuks A, Seemayer TA, Guttman RD (1989) Immunologic and genetic studies of diabetes in the BB rat. Crit Rev Immunol 9: 45-65

2. Butler L, Guberski DL, Like AA (1988) Genetics of diabetes production in the Worcester colony of the $\mathrm{BB}$ rat. In: Renold AE, Shafrir E (eds) Frontiers in diabetes research, Lessons from animal diabetes Vol 2. Libbey, London, pp. 74-78

3. Like AA, Guberski DL, Butler L (1991) Influence of environmental viral agents on frequency and tempo of diabetes mellitus in BB/Wor rats. Diabetes 40: 259-262

4. Scott FW, Mongeau R, Kardih M, Hatina G, Trick KD, Wojcinski Z (1985) Diet can prevent diabetes in the $\mathrm{BB}$ rat. Diabetes 34: 1059-1062

5. Carter WR, Hermann J, Stokes K, Cox DJ (1987) Promotion of diabetes onset by stress in the BB rat. Diabetologia 30: 674-675

6. Elder ME, MacLaren NK (1983) Identification of profound peripheral T-lymphocyte immunodeficiencies in the spontaneously diabetic BB rat. J Immunol 130: 1723-1731 
7. Woda BA, Like AA, Padden C, McFadden ML (1986) Deficiency of phenotypic cytotoxic-suppressor T lymphocytes in the $\mathrm{BB} / \mathrm{W}$ rat. J Immunol 136: 856-859

8. Greiner DL, Handler ES, Nakano K, Mordes JP, Rossini AA (1986) Absence of the RT-6 T cell subset in diabetesprone BB/W rats. J Immunol 136: 148-151

9. Greiner DL, Mordes JP, Handler ES, Angelillo M, Nakamura N, Rossini AA (1987) Depletion of RT6.1 ${ }^{+}$T lymphocytes induces diabetes in resistant BioBreeding/Worcester (BB/W) rats. J Exp Med 166: 461-475

10. Like AA, Kislauskis E, Williams RM, Rossini AA (1982) Neonatal thymectomy prevents spontaneous diabetes mellitus in the BB/W rat. Science 216: 644-646

11. Like AA, Biron CA, Weringer EJ, Byman K, Sroczynski E, Guberski DL (1986) Prevention of diabetes in BioBreeding/Worcester rats with monoclonal antibodies that recognize T-lymphocytes or natural killer cells. J Exp Med 164: 1145-1159

12. Metroz-Dayer M-D, Mouland A, Brideau C, Duhamel D, Poussier P (1990) Adoptive transfer of diabetes in BB rats induced by CD4 T lymphocytes. Diabetes 39: 928-932

13. Edouard P, Hiserodt JC, Plamondon C, Poussier P (1993) $\mathrm{CD} 8^{+} \mathrm{T}$-cells are required for adoptive transfer of the $\mathrm{BB}$ rat diabetic syndrome. Diabetes 42: 390-397

14. Ellerman KE, Wrobleski M, Rabinovitch A, Like AA (1993) NK cell depletion and diabetes in the BB/Wor rat (revisited). Diabetologia 36: 596-601

15. Shachner MS, Markmann JF, Bassiri H, Kim J, Naji A, Barker CF (1992) Direct assessment of the role of NK cells in autoimmune diabetes. J Surg Res 52: 601-604

16. MacKay P, Jacobson J, Rabinovitch A (1986) Spontaneous diabetes mellitus in the Bio-Breeding/Worcester rat: evidence in vitro for natural killer cell lysis of islet cells. J Clin Invest 77: 916-924

17. Komiya I, Baetens D, Inman L, Perrelet A, Orci L, Unger RH (1989) Morphometric and functional studies of islets in diabetes-prone $\mathrm{BB} / \mathrm{W}$ rats that are discordant for overt diabetes. Diab Nutr Metab 2: 263-267

18. Clarson C, Daneman D, Martin J (1986) Subclinical diabetes mellitus in the BB rat. Diabetes Res 3: 237-240

19. Kuttler B, Dunger A, Volk HD, Diamantstein T, Hahn HJ (1991) Prevention and suppression of autoimmune pancreatic beta-cell destruction in BB rats by syngeneic lymphocytes obtained from long-term normoglycaemic donors. Diabetologia 34: 74-77
20. Heding LG (1972) Determination of total serum insulin (IRI) in insulin-treated diabetic patients. Diabetologia 8: 260-266

21. MacKay P, Studstrup L, Gotfredsen C (1991) Passive transfer in the BB rat: onset time is inversely correlated with number of transferred T-helper cells. Diabetes 40 [Suppl 1]: 53A (Abstract)

22. Ewel CH, Sobel DO, Zeligs BJ, Bellanti JA (1992) Poly I:C accelerates development of diabetes mellitus in diabetesprone BB rat. Diabetes 41: 1016-1021

23. Nakamura N, Tstsumi Y, Kimata S et al. (1991) Induction of diabetes by poly I:C and anti-RT6.1 antibody treatment in DR-BB rats. Endocrin Japon 38: 523-526

24. Vives M, Soldevila G, Alcalde L, Lorenzo C, Somoza N, Pujol-Borrell R (1991) Adhesion molecules in human islet $\beta$-cells. De novo induction of ICAM-1 but not LFA-3. Diabetes 40: 1382-1390

25. Campbell IL, Iscaro A, Harrison LC (1988) IFN- $\gamma$ and tumor necrosis factor- $\alpha$. Cytotoxicity to murine islets of Langerhans. J Immunol 141: 2325-2329

26. Ko IY, Jun HS, Yoon J-W (1994) Studies on autoimmunity for initiation of beta-cell destruction $\mathrm{X}$. Delayed expression of a membrane-bound islet cell-specific $38 \mathrm{kDa}$ autoantigen that precedes insulitis and diabetes in the diabetes-prone BB rat. Diabetologia 37: 460-465

27. MacKay P, Studstrup L (1993) Old normoglycemic BB rats as donors and recipients of adoptively transferred diabetes. Autoimmunity 15 [Supp1 1]: 48 (Abstract)

28. Reddy S, Bibby NJ, Fisher SL, Elliott RB (1986) Longitudinal study of first phase insulin release in the $\mathrm{BB}$ rat. Diabetologia 29: 802-807

29. McCulloch DK, Klaff LJ, Kahn SE et al. (1990) Nonprogression of subclinical $\beta$-cell dysfunction among first-degree relatives of IDDM patients. Diabetes 39: 549-556

30. Beer SF, Heaton DA, Alberti KGMM, Pyke DA, Leslie RDG (1990) Impaired glucose tolerance precedes but does not predict insulin-dependent diabetes mellitus: a study of identical twins. Diabetologia 33: 497-502

31. Barnett AH, Eff C, Leslie RDG, Pyke DA (1981) Diabetes in identical twins: a study of 200 pairs. Diabetologia 20: $87-$ 93

32. Lo SSS, Tun RYM, Leslie RDG (1991) Non-genetic factors causing type I diabetes. Diabet Med 8: 609-618 